This is the author's final, peer-reviewed manuscript as accepted for publication. The publisher-formatted version may be available through the publisher's web site or your institution's library.

\title{
IMAGINING HEAVEN AND EARTH \\ AT MOUNT OF THE HOLY CROSS, COLORADO
}

\author{
Kevin Blake
}

How to cite this manuscript (APA format)

If you make reference to this version of the manuscript, use the following citation format:

Blake, Kevin. (2008). Imagining heaven and earth at Mount of the Holy Cross, Colorado. Retrieved from http://krex.ksu.edu

\section{Published Version Information}

Citation: Blake, Kevin. (2008). Imagining heaven and earth at Mount of the Holy Cross, Colorado. Journal of Cultural Geography 25(1):1-30.

Copyright: Copyright 2008 Taylor \& Francis

Digital Object Identifier (DOI): doi:10.1080/08873630701822588

Publisher's Link: This is an electronic version of an article published in Blake, Kevin, (2008), Imagining heaven and earth at Mount of the Holy Cross, Colorado. Journal of Cultural Geography 25(1):1-30. Journal of Cultural Geography is available online at: http://www.informaworld.com with the open URL of your article, which would be the following address; http://www.informaworld.com/openurl?genre=article\&issn=08873631 \& volume $=25 \&$ issue $=1 \&$ spage $=1$

This item was retrieved from the K-State Research Exchange (K-REx), the institutional repository of Kansas State University. K-REx is available at http://krex.ksu.edu 


\title{
IMAGINING HEAVEN AND EARTH \\ AT MOUNT OF THE HOLY CROSS, COLORADO
}

(Accepted for publication in the Journal of Cultural Geography,

vol. 25, no. 1, fall/winter 2007 issue)

\author{
Kevin Blake \\ Department of Geography \\ Kansas State University \\ Manhattan, KS 66506-2904 \\ Phone: 785-532-3406 \\ Fax: 785-532-7310 \\ E-mail:kblake@ksu.edu
}


Abstract. Rumors of a giant cross hidden deep in the Colorado Rocky Mountains finally proved true in 1873 with William Henry Jackson's photograph of Mount of the Holy Cross. Henry Wadsworth Longfellow and Thomas Moran further immortalized the cross, with many Americans imagining the peak as a Christian symbol of the righteous conquest of the West. Multiple geographical imaginations have since been quilted into the cultural fabric of the peak, such as a pilgrimage shrine, national monument, topographic oddity, Fourteener, and water wilderness. The place identity, spiritual geography, and iconography of these geographical imaginations are examined through participant observation and archival sources including folklore, poetry, newspaper articles, government surveys, and postcards. Some geographical imaginations prove to be unexpectedly temporary, such as the national monument designation, and others surprisingly enduring, such as pilgrimage. 
The mystique of Mount of the Holy Cross makes it one of the most notable peaks in all of North America. Rumors of a giant snowy cross hidden in the Colorado Rockies shrouded the peak in mystery from the mid-1800s until it burst upon the American imagination with the first photograph in 1873, proving to some that "God himself had blessed the westward course of empire" (Goetzmann and Goetzmann 1986, 182). Although most sacred mountains in North America are those of indigenous peoples, especially in the American Southwest, the geographical imaginations of Mount of the Holy Cross include a long history of Christian pilgrimage, and the very name of the place signals its role as a Christian shrine.

The peak is known more today for an accident of topography than for its religious symbolism, however. Its elevation in excess of 14,000 feet above sea level qualifies it as one of Colorado's famed Fourteeners, yet both its secular and sacred cultural constructs have persisted from discovery to the present day (Blake 2002). The layering of these geographical imaginations over time is the focus of this article.

The giant snow-filled cross on the east face of Mount of the Holy Cross is the most recognizable snowfield in Colorado (Borneman and Caudle 2005). The cross formed when a rugged, steep, narrow gully in the rock (a couloir) developed in a seam of schist that is weaker than the surrounding gneiss. Beginning at the summit of 14,005 feet, the defile, named the Cross Couloir, plunges down the mountain for approximately 1,200 feet. About a third of the way down intersecting arms branch out following joints in the rock that are each over 200 feet wide. ${ }^{1}$ What makes the couloir and intersecting benches unique is that they collect more snow than the rest of the sheer east face, and after the spring melt the snowy cross stands in sharp relief against the dark rock of the summit cone (Figure 1). 
Located about 80 miles west-southwest of Denver, Colorado, Mount of the Holy Cross is the northernmost Fourteener in the Sawatch Range and the only one in this range located west of the Continental Divide. Such a distinctive snowy mark might be assumed to be widely known, but the cross is only visible for a short time in summer, and then only from a handful of mountain peaks and passes. But the key element adding doubt to the early rumors was that although Mount of the Holy Cross could be easily seen from several Fourteeners to the east, as a person travels nearer to the peak the looming mass of Notch Mountain (13,247 feet), located less than one mile east of the snowy cross, obscures the view.

\section{IMAGINING MOUNTAINS}

Few landscapes have an unambiguous meaning to all people for all time. More often, the symbolism of place will be molded to the beliefs of various cultures, perhaps in conflicting ways, and the symbolism will be re-shaped to fit changing ideals over time (Tuan 1974). New representations may creep into a collective consciousness over centuries, or newly understood meaning can occur overnight. Mountain symbolism, for example, has in general evolved from association with fear and evil, at least in the context of Western civilization, to sublime and beautiful landscape over the course of the past four centuries (Nicolson 1997). Amidst this broad trend, however,

the geographical imaginations of an individual peak - the way it is conceptualized to fit cultural ideals particular to a time and place - can remain constant for centuries in the eyes of one group of people even while its meanings change rapidly for another group (Blake 2005). 
Understanding "the place of the imagination in geographical studies" is intimately tied to the Siren call to explore unknown lands (Wright 1947, 1). The mysterious qualities of Mount of the Holy Cross have emitted various Siren calls to different individuals and groups for at least 150 years, yet the label terra incognita was inapplicable to Native Americans: Euro-Americans were the ones fascinated by the peak's alluring image. This article explores the subjective matters that have kindled the geographical imaginations of the mountain from the perspectives of place identity, spiritual geography, and iconography that thread their way through the geographical imaginations.

Place identity, the meaning of a place to a group of people that gives a stronger sense of shared belonging, is manifest in the appropriation of the peak as a symbol of local communities, Colorado, and the nation (Blake 1999a). The desire to create identity and give order to a place has also added significance to the mountain's elevation and wilderness qualities. The nature of the place identity of Mount of the Holy Cross is best understood coupled with the context of spiritual geography, the study of the places with relevance to human spirituality and how this place-based spirituality is shaped by events and other places (Francaviglia 2003). Interwoven with the physical world of mountains are beauty, meaning, and purpose. The spiritual reactions to Mount of the Holy Cross resulted in its role as a sacred place and pilgrimage shrine, not only to Christians but also to thousands of hikers seeking climbing challenges or, as with John Muir, transcendental experiences based on the admiration of God's creation set in a scenic alpine landscape (Muir 1993). Indeed, the serrated ridges, turquoise lakes, snow-filled couloirs, and mystical towering peaks of the Holy Cross landscape caused one experienced mountaineer to compare this place with the sacred landscape of the Himalaya (Kerasote 1987). 
Much of the place identity and spiritual geography of this peak is communicated by its iconography, the collected pictorial representations or symbols of the mountain that convey its symbolic meaning. Applying iconography to the study of a landscape is a powerful tool in understanding the symbolism of place, whether secular or sacred (Cosgrove and Daniels 1988; Blake 1999b). Identifying key landscape icons and asking a series of questions that lead from source to symbol (Meinig 1979, $173)$ is a key perspective underlying this article. The creation of a deeply symbolic mountain is typically built with many icons emanating from the landscape memories and imaginations of countless individuals and groups (Macfarlane 2003).

There may be no mountain more identified by its visual imagery than Mount of the Holy Cross. Photographs and postcards form a rich repository of the visual images and a benchmark to assess changing geographical imaginations (Stewart 1953; Vale and Vale 1983; Vale and Vale 1994; Shortridge 2000; Arreola 2001; Jakle 2003; Wyckoff 2006). I also rely on many archival sources for this essay, such as folklore, poetry, government surveys, newspaper articles, climbing registers, and hiking guides. Central to my understanding of the lure and lore of the peak are my experiences in the field, including multiple visits to the northern Sawatch, participant observation while mountain climbing, and analysis of the nearby landscape, a valuable way to understand the imprint of culture on place (Parsons 1977; DeLyser and Starrs 2001).

In one sense Mount of the Holy Cross is an instance of exceptionalism: it is a rare example of a sacred American mountain to a non-indigenous population. Even though spirituality is at the core of its image, Mount of the Holy Cross is also a case study of the defining characteristics of the Mountainous West: barriers, islands of moisture, areas of government control, zones of concentrated resources, restorative sanctuary (Wyckoff and Dilsaver 1995). As Wright (1947) suggests in his seminal work 
on the study of geographical imaginations, or geosophy, understanding the geographical imagination of the peak is often an issue of scale, from intense local meaning to artists and hikers to vague national symbols of religion and Manifest Destiny. The accumulated symbolism of the mountain is presented here in approximately chronological fashion, as each event, though varied in nature and intensity, built upon and reinterpreted prior geographical imaginations. Most of the Mount of the Holy Cross literature focuses exclusively on the late nineteenth and early twentieth centuries. Those were heady days in the cultural history of the mountain, to be sure, but that focus ignores some continuing threads in how the peak has been imagined, such as a symbol for Colorado, as well as several new themes, such as wilderness management issues.

\section{QUEST FOR THE SNOWY CROSS}

Though the snowy cross was likely known to miners and other Coloradans, the first recorded sighting was in 1868 by Samuel Bowles, editor of the Springfield, Massachusetts Republican, from the summit of Grays Peak, an easily-climbed Fourteener located 37 miles to the east (Bueler 2000). ${ }^{2}$ His observations indicate that from the start the peak's namesake feature was viewed in religious terms:

Over one of the largest and finest [ranges] the snow-fields lay in the form of an immense cross, and by this it is known in all the mountain views of the territory. It is as if God has set His sign, His seal, His

promise there, -- a beacon upon the very center and hight [sic] of the Continent to all its people and all its generations (Bowles 1991, 117). 
Bowles, however, did not refer to the mountain by name, as did William H. Brewer, an agriculture professor at Yale on an 1869 expedition led by Harvard geology professor Josiah D. Whitney to measure mountain elevations. Also looking westward from Grays Peak, Brewer wrote that "The Mount of the Holy Cross was forty miles away, with its cross of pure white, a mile high, suspended against its side" (Brewer 1930, 49).

At the opening of the "Great Survey" era of government-sponsored expeditions to the Mountain West in late 1860s, Mount of the Holy Cross was thus known by name and sight, but still undocumented by photography and in the realm of a rumored topographic oddity. As part of the "effort to demystify the secrets and scenery of the Colorado mountains" (Wyckoff 1999, 90), the 1873 survey of the Colorado territory led by Ferdinand V. Hayden set as one of its primary goals the photographing and measuring of the fabled cross. To that end the party included surveyor James T. Gardner, topographical illustrator William Henry Homes, and photographer William Henry Jackson. The Hayden Survey was easily able to pinpoint the location of Mount of the Holy Cross with triangulations from afar, yet the expedition members met no one with firsthand knowledge of how to access the peak. Still, toward the end of the summer survey season, the explorers amassed enough topographical knowledge to follow a creek valley (subsequently named Cross Creek) in a southwesterly direction from the Eagle River toward the base of the mountain (Jackson 2005).

The trials and tribulations of travel through unknown lands during the next few days, combined with what the expedition ultimately accomplished, are legendary. The terrain never offered a view of their objective, and their progress slowed to a crawl across narrow ledges, tremendous rock slides, dark chasms, and densely timbered slopes. Hemmed in the valley, they dealt with swampy ground and mountain 
slopes "that bristled like a porcupine. Countless multitudes of giant pine-trunks, uprooted by some fierce hurricane, were piled up and crisscrossed in such a way that an army must have stopped as before the walls of an impregnable fortress" (Holmes 1875, 209). Any terrain not fallen timber or bogs sprouted thousands of smooth, glacially-polished rocks that reminded the explorers of a million white-backed sheep; they named them roche moutonées.

To make better progress the expedition split into two groups on 23 August 1873, one to climb and survey Mount of the Holy Cross, led by Gardner and Holmes, and one to photograph the cross from Notch Mountain, led by Jackson (Figure 2). Torrential rain, steep cliffs, and dense forests impeded both groups. Jackson forged ahead alone late in the day to the northwestern shoulder of Notch Mountain, where the clouds briefly parted for a glimpse of "the Holy Cross in all its sublime impressiveness ... the marvelous mountain on which nature had drawn with mighty lines of snow the symbol of the Christian world" (Jackson 2005, 113). Before the rest of his party reached him the clouds again obscured the peak, but Jackson took it as a benedictional sign that a circular rainbow appeared floating on the mists in the valley below Notch Mountain and Mount of the Holy Cross. The survey party fared no better in completing their task, so both groups spent a cold, wet, hungry night high on the slopes, separated from each other by what would be a difficult climb but what was only a short straight-line distance across the narrow valley of East Cross Creek. They were able to spot each other's campfires and cheer themselves by shouting greetings across the void (Holmes 1875).

Sunday, 24 August 1873, dawned clear, and both parties quickly achieved their goals. Jackson's exposure of one $11 \times 14$ and seven $5 \times 8$ plates of the snowy cross from the northwestern shoulder of Notch Mountain proved to be the monumental 
achievement of the survey (Figure 1). The photography was especially valuable given the difficultly in even gaining a close-up view of the cross. Even today, views of the cross are rare, with no better nearby viewpoint than rugged Notch Mountain. ${ }^{3}$ Jackson's photographs thus became at once the dominant iconography of the mountain, firmly emblazoning the peak's eastern face in the public mind. With the countless photographs, paintings, and postcards images of the snowy cross, it is difficult to remember that another face of the mountain exists, despite the fact that the approach of the main hiking trail offers no view of the cross (Figure 3). Some climbers are so befuddled by this that they comment in the summit climbing register, "Where is the cross"?

The 1873 photographs are unparalleled in their presentation of a perfect cross. Though the photographs "provided a sense of realism and immediacy heretofore impossible to grasp" (Wyckoff 1999, 90), the ideal nature of the cruciform that day later contributed to debates over the veracity of Jackson's images and changes in the cross form. Jackson hardly rested in his quest to re-photograph the mountain, visiting again in $1880,1893,1897$, and 1905 , but he never could replicate the quality of the cross as he photographed it in 1873 (Brown 1970). Jackson's perspective of the cross is so well known that a commemorative plaque was placed on Notch Mountain to mark the site of his first photographs, and another plaque was placed on the summit of Notch Mountain to indicate that Jackson's photographs were not taken there (Foster 1987). The aura of scientific objectivity surrounding photography served Jackson's work well, legitimizing the image of the cross in 1873 as the ideal view and facilitating the appropriation of nature as a commodity to a far wider audience than possible with landscape painting (Cosgrove 1984). Even as the peak later attracted the potent image-making skills of acclaimed painters and poets, Jackson's first 
photography reigns as the supreme event in the geographical imagination of Mount of the Holy Cross.

\section{POPULARIZING THE PEAK}

Jackson's photograph of Mount of the Holy Cross became the most famous image ever made of an American mountain (Goetzmann and Goetzmann 1986; Hales 1988), but its two most important immediate effects were establishing the mountain as a Christian symbol and inspiring painter Thomas Moran to visit the peak. Already famous for his images of Yellowstone while in the employ of the 1871 Hayden Survey, Moran chose to travel with the John Wesley Powell Survey in 1873 in order to paint the Grand Canyon. Powell knew of Moran's unique abilities to capture the West on canvas: “Two classes of mountains are represented in paintings. [Frederic] Church paints a mountain like a kingdom of glory. [Albert] Bierstadt paints a mountain cliff where an eagle is lost from sight ere he reaches the summit. Thomas Moran marries these great characteristics, and in his infinite masses cliffs of immeasurable height are seen" (Powell 1961, 389). Fresh on the heels of the renowned success of Grand Canyon of the Yellowstone (1872) and Chasm of the Colorado (1873-74), Moran set out in the summer of 1874 to see Jackson's snowy cross. Knowing the correct route did not make for easier travel, as Moran struggled through the wet conditions and fallen timber that plagued the Hayden Survey a year earlier. He eventually reached Notch Mountain and a view of the cross, yet made few sketches due to the poor weather (Brown 1970).

Relying heavily on the details of peak from Jackson's photograph with highlights added from his own quest, Moran painted Mountain of the Holy Cross in 1875 
(Figure 4). Like Jackson, he would return multiple times to this subject, but most critics prefer his first image (Brown 1970). The painting hung in the main art gallery at the 1876 Philadelphia Centennial Exhibition where it garnered a medal and diploma, but even more importantly it contributed to immortalizing the West in the national mindset (Kinsey 1992). A Jackson print was also displayed in Philadelphia, winning seven medals (Jenkins 1976).

Images based on Moran's painting quickly joined Jackson's photographs in forming the dominant visual representations of Mount of the Holy Cross, overwhelming any sense of the feature as a topographic oddity and providing the "visual proof of the uniqueness of western landmarks" necessary for later preservation efforts (Runte 1979, 14). Ironically, both artists received some criticism for manipulating their work, with Jackson re-touching some plates to add a waterfall and Moran re-configuring the orientation of Cross Creek to place it in the foreground view of the cross (Carhart 1932). In neither case did the artist fabricate any scenic element from thin air (Brown 1968); Jackson relocated the waterfall on East Cross Creek farther upstream and Moran achieved a more pleasing composition by providing just a suggestion of the fallen timber amid the relocated waterfall and creek. Highlighting these small yet significant water features in their art established Jackson and Moran as early popularizers of the notion that sacred mountain wilderness in America combines rugged terrain with water.

Moran's painting helped shape the geographical imaginations of the peak in two additional ways. First, by placing the snowy cross near the top center of canvas and re-positioning the foreground water elements to lead the eye straight toward the cross, Moran contributed significantly to the Christian symbolism of the mountain. Second, in the same way that Jackson's photograph motivated Moran, the painting 
inspired one of America's most popular poets of the nineteenth century, Henry Wadsworth Longfellow, to pen "The Cross of Snow" in 1879.

Upon viewing Moran's landscape in a book about western scenery, Longfellow wrote the sonnet as a sorrowful and private memorial to his second wife, Fanny, who died eighteen years earlier. Found in his papers after he died in 1882, the poem became one of Longfellow's most famous (Brown 1970). Longfellow's words gave literary form to the ethereal and sublime images of Jackson and Moran:

There is a mountain in the distant West That, sun-defying, in its deep ravines Displays a cross of snow upon its side. Such is the cross I wear upon my breast These eighteen years, through all the changing scenes And seasons, changeless since the day she died (Longfellow 2000, 671).

The claim of Christianity upon the geographical imagination of Mount of the Holy Cross relied heavily on the imagery established by Jackson, Moran, and Longfellow and stories of their efforts to immortalize the cross of snow. As if the cross was not enough for Christians to take as a sign of divine approbation, the snowfield to the right of the cross in Jackson's photographs became known as the Supplicating Virgin for its supposed resemblance to the Madonna reaching out toward the cross (Jackson and Marshall 1952). The naming of the entire landscape became rife with Christian metaphor: the vertical arm of snow became the Cross Couloir, the glacial tarn at the foot of the couloir became the Bowl of Tears (akin to the cup catching the blood of Christ), and the stream became Cross Creek. 
Christianity's influence in the geographical imaginations of the peak is illustrated in a legend published in 1896. It spins a yarn about a party of Spaniards including a friar that have become separated from the conquistadors and entered unknown mountains, where they encounter the fabled Wandering Jew. The Spaniards give succor to the weak old man, and when he awakens the next morning he claims to have dreamt that he finally gains forgiveness for his sins and will sleep forever beneath the cross. Soon the Wandering Jew is found dead among the mountain grass, and there he is buried and blessed by the friar. That night a tremendous storm roars through the mountains, and in the morning the Spaniards find that the grave of the Wandering Jew is isolated from their camp by a newly formed chasm, and above the grave is an unscalable mountain precipice. The following summer a mighty cross of snow appears above the grave, serving as an eternal symbol of God's benediction upon mountain travelers (Field 1896). The legend may sound fantastical today, but in the religious mindset of its day it was proof that the mount was of God's hand and that the path to salvation was through Christianity.

No aspect of popular culture was free from the Christian symbolism of the Mount of the Holy Cross. The sheet music for "A Trip to the Rockies" in 1901 featured Moran's painting on the cover and a poem by Will L Vischer: "The holy cross of Christian faith, / Above the royal velvet / In beauty shines, an emblem wraith, / High on beetling helmet” (Ingram 1901). A guidebook to Colorado published in 1911 quoted Alva Adams in saying "the Almighty with everlasting snow has painted the symbol of masonry - the cross of Christianity," and also a poem by Marion Muir that evokes the cross as a sign of God in the wilderness for westward moving settlers (Parsons 1911). By the 1920s, Mount of the Holy Cross had become a staple in any portrayal of Colorado mountains, whether in souvenir photography books (Among 
the Rockies 1907), travel guides (Crofutt 1981), hiking tales (Chapin 1995), poetry (Kerin 1922), or postcards (Figure 5).

\section{A NATIONAL SHRINE}

By the 1920s, Mount of the Holy Cross was one of the best known mountains in the world (Carhart 1932). A photo of the peak hung in the Vatican (Picturesque Colorado 1909). Interest in the mountain, while primarily expressed in iconographic terms, had also spawned religious quests. The first recorded pilgrimage was in July 1912, when Benjamin Brewster, Episcopal Bishop of Western Colorado, performed a Holy Eucharist on top of Notch Mountain (Jenkins 1976). Access to the peak was still difficult, but community leaders in the nearby towns of Red Cliff and Minturn were intent on improving the roads and promoting the prospect of pilgrimage.

In the early 1920s, O.W. Daggett, publisher of the Red Cliff newspaper, The Holy Cross Trail, convinced the Forest Service to set aside 350 acres as a devotional area in Holy Cross National Forest along Shrine Pass, a high mountain road (elev. 11,089 feet) approximately 13 miles northeast of Holy Cross. ${ }^{5}$ Daggett's dream included building a 50,000 seat amphitheater, campground, and golf course (Brown 1970). None of these developments came to fruition, largely because the pilgrimage focus stayed fixed on Notch Mountain due its closer proximity to the cross. But the Shrine Pass viewpoint is still marked by the Forest Service today, with a short trail leading through the spruce-fir forest to an overlook and a plaque of a Bible verse embedded in granite (Figure 6).

With Minturn billing itself as "Gateway to the Mount of the Holy Cross" and Red Cliff leaders advocating for a transcontinental route called the Holy Cross Trail 
from New York to San Francisco that would utilize Shrine Pass, the prospect for road improvements and pilgrimage seemed bright. Not all Coloradans, however, imagined the improved access and increased numbers of visitors in positive terms. The Colorado Mountain Club (CMC) planned an August 1923 outing to Mount of the Holy Cross. It was billed as perhaps the last outing to the area before the newly constructed roads would spoil it with "thousands of high-heeled tourists." The announcement continues:

Now is the time to see it BEFORE it is desecrated in the name of religion. It is a glorious mountain, in a splendid and so-far inaccessible setting of ragged ridges and sparkling lakes. We want to visit it while the mystic lure and friendly solitude still surround it. And to do this we must go at once. For the roadbuilders are busy and the toot of the auto horn is approaching fast (Bergin 1923, 11).

Although the dominant geographical imagination of Mount of the Holy Cross was framed by Christian beliefs, another group of people saw the peak as a symbol of outstanding mountain scenery and solitude. Ironically, although the CMC members dreaded the idea of mass pilgrimage, the after-trip report noted the "poor" views of the cross due to the late summer season (Bouck 1923). It was as if no trip to the area would achieve fulfillment, whether of the religious or recreational kind, without a view of the cross as it appeared in Jackson's photos and Moran's paintings.

The key support that launched eleven consecutive years of significant national pilgrimages beginning in 1928 came from the editor of The Denver Post, Frederick Gilmer Bonfils, and his promotions in the newspaper and financial support for road improvements (Crouter 1977). Approximately two hundred Catholics and Protestants from twenty-five states and Canada hiked to the summit of Notch Mountain in the 
July 1928 pilgrimage, with reports of a miraculous cure leaving no doubt that greater numbers of pilgrims would be on their way (Fryxell 1934).

The pilgrimage prompted President Herbert Hoover to use the Antiquities Act to declare Holy Cross National Monument on 11 May 1929. Setting aside 1,392 acres encompassing the summits of Notch Mountain and Mount of the Holy Cross, Presidential Proclamation 877 notes the "figure in the form of a Greek Cross" that is “an object of much public interest" (Hoover 1929, 19). New road and facility construction came rapidly with the national monument status. An auto road was built from the Eagle River southwestward toward Notch Mountain, first to Camp Tigiwon (a Ute word meaning "friends") in 1932 and then closer to Notch Mountain at Halfmoon Campground in 1933 (Gaug 2003). The Tigiwon Community House was built to shelter pilgrims, with over 600 pilgrims arriving in 1932, over 800 in 1933, and over 3,000 in 1934 (Birch 1935). Content with the view of the cross from Notch Mountain, few pilgrims climbed Mount of the Holy Cross. The Forest Service built a horse trail to the south summit of Notch Mountain, and two hundred workers of the Civilian Conservation Corps built a stone shelter house there at a cost of $\$ 120,000$ (Fryxell 1934; Gilliland 2004). Expectations were that over one thousand visitors a day would arrive at Holy Cross within a few years, and plans were made to construct at Camp Tigiwon an administration building, post office, dining hall, rental cabins, parking lots, water system, and a larger community hall (Birch 1935).

The pilgrimage phenomenon was not limited to actual visitors: "handkerchief healing” was inspired by Acts 19:12 (Eberhart and Schmuck 1970). During the 1928 pilgrimage, a Denver pastor promised the sick in his congregation that they would be healed in they kneeled in prayer at the appointed hour. When he returned, he was "swamped with assertions of cures" (Fryxell 1934, 9). He instructed anyone unable to 
make the next pilgrimage to send him a handkerchief that he would take with him. About one hundred handkerchiefs were blessed in 1929, with astonishing reports of cures afterwards. By 1932, he received over 2,000 handkerchiefs from throughout the nation, requiring the help of the Forest Service to haul the load up Notch Mountain (Fryxell 1934). Mount of the Holy Cross had become an example of transmutation, the process by which religious worship was transferred from cathedrals to the mountain landscape. The belief system was the same, the holy dates the same, the symbolism of the cross the same, but the mountain landscape had become sacred (Carhart 1932; And Now 1933).

\section{A FALLEN CROSS}

Oddly, right at the height of the popularity of pilgrimages and the image of the peak as a sacred mountain, the pilgrimages ceased in 1938 (Brown 1968). The planned improvements at Camp Tigiwon were left on the drawing board. Although the pilgrimages can be conceptualized as a "fad" that ran out of steam (Lavender 1976, 172), the difficulties in reaching this remote area likely played a major role. No amount of development at Camp Tigiwon could offset the tortuous mountain roads leading to the area, the effect of high elevation on pilgrims, or the struggle to ride horseback or hike over steep, rugged terrain to Notch Mountain. Furthermore, the death of editor Bonfils in 1933 left the pilgrimage without its most ardent promoter (Crouter 1977).

The U.S. Army likely had the greatest influence over the end of the pilgrimages, however, with the establishment in 1942 of Camp Hale (Borneman and Lampert 1998). Mountain and winter warfare training exercises were conducted until 1965 in this area of over 200,000 acres from the headwaters of the Eagle River right 
up to the boundaries of Holy Cross National Monument. The combination of the Depression extending into the 1930s, gas rationing during World War II, and the prohibition of civilian travel within Camp Hale (Wolle 1949) ensured the demise of the large national pilgrimages.

With the decline in public interest in the peak, Holy Cross National Monument was abolished by Congress on 3 August $1950 .^{7}$ The superintendent of Rocky Mountain National Park, who administered Holy Cross National Monument, supported the abolishment because fewer than fifty people visited the monument each year and it was "a climb worth half your life" to climb Notch Mountain for a view of the cross (Brown 1968, 38).

Rumors of the ruination of the right arm of the cross further supported the abolishment of the national monument while simultaneously discouraging the resumption of large pilgrimages (Brown 1968; Lavender 1976). As for when the cross arm changed appearance - if it changed - the war effort, lack of visibility, and climatic conditions all cloud the view (Figure 7). Rumors of a rock slide in the right arm were unsupported by visual evidence, yet to most observers the snowy cross has not appeared in its earlier form of classic perfection since the 1930s (Brown 1968). Most observers assumed that natural forces altered the cross, but artillery shelling or the vagaries of human perception might have played key roles. One rumor suggested that artillery shelling from the summit of Notch Mountain had blasted the right cross arm, but neither Army records nor the first-hand examination of the cross by climbers in 1951 supported this tale (Brown 1968). Of course, ground vibrations from nearby shelling could have been the veritable straw that broke the cross's back in causing some change in the rock fracture along the cross arm. It is also possible that the snow and atmospheric conditions observed by Jackson in 1873 have never again been 
duplicated. Ample evidence exists of the changes caused by global warming in snow, ice, and glacial conditions; surely a small snowfield in a rock crevice could appear greatly different from decade to decade.

The repeated doctoring of images of the cross by publishers in an effort to achieve a mythical yet ideal cross also resulted in the unrealistic visitor expectations to see a perfect cross and view anything else as something of a topographic oddity. The thousands of re-touched lithographs, woodcuts, postcards, paintings, and photographs ensured that no matter what image a visitor hand in mind of the cross, it was unlikely to be faithfully duplicated on site (Figure 8). The mere existence of the national monument would also have raised expectations of a perfect cross. With the lore of the pilgrimages and a steady stream of folklore suggesting a divine presence in the cross it is easy to see how the belief in the eternal character of the mountain was reduced greatly by reports of the diminished physical integrity of the cross.

Ironically, just as the national monument was abolished, a local effort was mounted to have Mount of the Holy Cross on a commemorative stamp to be issued in 1951 for the $75^{\text {th }}$ anniversary of Colorado statehood. The stamp effort faced long odds, though, since only six commemorative stamps were issued in 1951, and a state typically warranted a commemorative stamp only on the centennial of territorial designation or statehood. The Holy Cross Postmasters' Association, based in Minturn, sent a resolution supporting the stamp idea and copies of Jackson's photograph to thousands of postmasters and religious, fraternal, and civic organizations around the world. The resolution touted the (fabled) discovery of the cross by Coronado and its worldwide religious significance. Support for the stamp poured in from hundreds of Kiwanis and Lion's clubs, chambers of commerce, American Legion and VFW posts, and newspaper editors, as well as fifty-four postmasters of foreign countries, Eleanor 
Roosevelt, and Winston Churchill. The effort proved successful as the stamp prominently featured Mount of the Holy Cross when issued on 1 August 1951. The significance of the local effort and symbolic importance of the mountain among the stamp icons was affirmed by the issuance of the first day of issue postmark at Minturn (Figure 9).

\section{THE NEWEST FOURTEENER}

Just as Mount of the Holy Cross seemed to have run its course in geographical imaginations as a sacred mountain, topographic oddity, national monument, and state symbol, another government survey of elevations altered yet again the cultural course of the peak. Although the Hayden survey established the elevation of Mount of the Holy Cross as 14,170 feet, by the 1920 s other surveys had removed the peak from the Fourteener aristocracy with a measurement of 13,978 feet (Fryxell 1934). In the 1950s, the estimate was back up to 13,996 feet, but without the Fourteener status and amid reports of a diminished cross, the mountain had "lost some of its luster" (Eberhart and Schmuck 1970, 33).

The summit registers indicate that at most a few dozen people climbed Mount of the Holy Cross each year in the 1950s, but not all hikers were content to stop a few feet short of fourteen thousand. ${ }^{8}$ The 18 August 1954 register indicates a three-foot cairn (rock pile) had been added to the summit, and another on 6 October 1963 notes "we built it up to 14,000 - hope winter winds won't blow down our unstable cairn."

With several decades spent on the Fourteener list in the late 1800s and early 1900s, the elevation of the summit apparently mattered greatly in the geographic imagination of the mountain, as is the case with mountains throughout human history (Wright 1966). 
The cairns were redundant after the 1964 re-survey with a new elevation of 14,005 feet. Both of the CMC registers that straddle that era mention the new elevation, with a 18 June 1966 entry noting that the peak is now a "14er," and the 1967 entries wishing, "Happy New Year, 14er's.” A ranking of 53 on the list of 54 Fourteeners spawned an immediate increase in the number of climbers signing the summit register: 188 in 1966, approximately 800 in 1978, and nearly 1,200 in 1988. Hikers began to take notice of peak's climbing popularity, with one writing on 24 July 1978, “There are too many damn people here.” By 1995, an annual total from the summit registers is impossible to estimate since the registers were not replaced frequently enough to record the thousands of climbers, but in just a three-week period from August 15-September 6, 1995, approximately 570 people climbed the mountain.

The skyrocketing numbers reflected a fascination with 14,000 feet far more than the ease of the climb. The Cross Couloir offers one of the classic climbing challenges on a Colorado Fourteener, and the main climbing route up the north ridge is infamous for its distance of 12 miles round-trip and great elevation gain (5,625 feet) from the trailhead at Halfmoon Campground to the summit (Roach 1999). The terrain is "remote, forbidding, and dangerous" (Brown 1970, 27), and every few years there is a highly-publicized fatality on the mountain.

The prospect of death at high elevation discourages few climbers. At the summit on 31 July 1998, I unexpectedly met Tomas, a Slovak currently living in Prague, and H.J., a Mexican-American from Dallas. Tomas was visiting a friend in Vail and sought out the nearest Fourteener, traveling from Vail to Minturn by bus and then hitchhiking to the trailhead. H.J., who cut his climbing teeth on the high volcanoes of Mexico as a boy, flew from Dallas to Denver the night before the hike then drove to the trailhead and slept in his car. It was an expensive and highly anticipated three-day 
weekend for him as he attempted to climb at least two Fourteeners without the benefit of acclimatizing to the high altitude. We had each come to the mountain seeking solitude and beauty, yet meeting high on a mountain often forges camaraderie among hikers. For a delightful hour in the rarefied air we talked and admired the limitless view of stunning wilderness scenery. The aerie of the summit cone offered us one of the more dramatic sights on a Fourteener: a view 2,000 feet straight down Cross Couloir to the Bowl of Tears, sparkling vivid turquoise like a gemstone in the rough (Figure $10)$.

\section{A WATER WILDERNESS}

Protected wild nature is one of the dominant images for western landscapes (Vale and Vale 1989). Wild nature in the Colorado Rockies, though, invariably means water, whether it is a cascade, lake, tarn, stream, or wetland meadow (Douglas 1961). As more hikers became familiar with the iconic features of liquid or frozen water on and near Mount of the Holy Cross during the outdoor recreation boom of the 1970s, the spectacular scenery spurred the congressional designation in 1980 of over 48,562 ha $(120,000$ acres) as the Holy Cross Wilderness. As presaged by the Colorado Mountain Club (CMC) outing in 1923, however, thousands of visitors to the wilderness were soon seen as overusing the resource, i.e. loving it to death (Nash 1967; Gilliland 2004). To protect the wilderness, the CMC in 1988 proposed closing campsites along East Cross Creek and encouraging day use only (Vickery 1988). The goal was to avoid a permit system, yet in 2003 White River National Forest implemented a mandatory, but free permit system, for the wilderness. The permit 
numbers are not currently limited; the goal first is to acquire better data on levels, locations, and types of use.

Wilderness, a word with legal standing, still manages to conjure greatly different geographical imaginations on the part of users. The Forest Service, in an attempt to keep hikers on one route rather than creating a network of casual trails, placed five-foot cairns along the main hiking trail, but wilderness purists who object to that sort of intrusion on the landscape repeatedly dismantled the cairns. Other hikers, apparently in an effort to improve the trail marking, vandalized dozens of trees and rocks with spray-painted white arrows. Oddly, the arrows often mark a more difficult route or were painted where the trail is obvious (Lipsher 2005).

The most serious competition for wilderness resources at Mount of the Holy Cross, however, involves water. The Piedmont cities, including Denver and its suburbs, such as Aurora, and Colorado Springs, covet central Colorado's water (Crowley 1975). With roughly $80 \%$ of the precipitation falling on the western slope of the Continental Divide where only $20 \%$ of the population lives, transmountain water diversions are a Colorado way of life (Treese 2005). Utilizing water rights acquired in 1962 to numerous Eagle River tributaries, the Homestake Water Collection and Storage System, jointly owned by Aurora and Colorado Springs, transfers water in a tunnel below the Continental Divide from Homestake Reservoir on the western slope in the southern portion of the Holy Cross Wilderness to Turquoise Reservoir on the eastern slope.

The 1980 act that created Holy Cross Wilderness Area preserved the rights of the cities to expand the Homestake Project. In 1981, the cities issued a draft environmental impact statement (EIS) for the $\$ 90$ million Homestake II Project that would divert an additional 20,000 acre-feet of water from the Holy Cross Wilderness 
Area. A new tunnel would divert over $90 \%$ of the spring snowmelt from several wilderness area creeks to the Homestake Reservoir and then the eastern slope. The first Forest Service report claimed minimal impact on wetlands and fisheries from Homestake II, but pressure from conservation groups and the formation of the Holy Cross Wilderness Defense Fund resulted in the completion of a full EIS in 1983. It also asserted minimal impact on the wetlands, but the battle for the dominant geographical imagination of Holy Cross Wilderness - water resource or water wilderness - was just beginning to heat up.

The qualities of the wilderness related to water were quickly summarized by the wilderness defenders: "five glaciated valleys, eighty-seven alpine lakes, and Cross Creek, the longest high altitude stream running entirely within designated wilderness" (Illg and McClellan 1983, 155). They tapped into a powerful truism in the American perception of mountains and wilderness: people expect to see water in a Rocky Mountain wilderness. This mindset was manifest and codified when all early national parks were established in moist mountain environments, such as Yellowstone, Yosemite, Sequoia-Kings Canyon, Glacier, Rainier, and Great Smoky Mountains (Vale 1995).

The juxtaposition of mountain wilderness and water is furthered by the symbols of the Holy Cross Wilderness Defense Fund. The "Help Save Holy Cross Wilderness" brochure produced in the 1990s prominently features photographs of waterfalls, wetlands, and the phrase, "water is the lifeblood of wilderness," whereas the logo of the organization features the mountain cross. Interestingly, this current secular theme of water as lifeblood echoes Biblical prophesies and proclamations about living water in a physical and spiritual context, and serve as a foundation of Christian theology (e.g., Isaiah 35:6, John 4:14, John 7:38). 
The Holy Cross Wilderness Defense Fund joined with the Sierra Club and Eagle County in opposing the project through several lawsuits, and then the Eagle County Commissioners denied a permit for the project. The opposition was based on potential environmental damage to rare wetland plants plus the potential need for water by Eagle County business interests. Eagle County's decision was upheld by the Colorado Supreme Court and, in December 1995, by the U.S. Supreme Court when justices refused to hear the case. The water is still there, however, and stakeholders from both sides of the Continental Divide continue to discuss water development options in the Eagle River watershed (Treese 2005).

\section{A PEAK OF IDENTITY}

Over the past 130 years the fame of Mount of the Holy Cross has waxed and waned as the geographical imaginations of the place have been re-shaped by differing visions of place identity, spiritual geography, and iconography. The mountain has been conceptualized as a peak of identity for local communities, Colorado, the nation, and the Christian world. Often these scales have intertwined, such as when the local stamp boosters enlisted the support of foreign postmasters, or when Christian pilgrimages resulted in the designation of a national monument that gave local communities a short-lived economic boost. Even which local towns are at the heart of the peak's identity has evolved, from Red Cliff early in the twentieth century to Minturn by midcentury, with Eagle, Glenwood Springs, and Vail on the periphery of its geographical imaginations.

Minturn lays the strongest overt claim to the mountain with snowy cross icons on Saint Patrick's Parish Chapel, a local car wash, cemetery markers, and the town 
logo (Figure 11). The local electric utility headquartered in Glenwood Springs, Holy Cross Energy, also unabashedly projects the image of Jackson's perfect cross in its web site (www.holycross.com), newsletter, name, and signage. Though the mountain is perhaps less well known today than in the 1930s, its majestic icon still is co-opted by a wide variety of businesses and organizations.

Pilgrimage to Mount of the Holy Cross is widely reported in the literature to have ceased in the 1930s, but those were only the large-scale Christian pilgrimages organized by The Denver Post. In the spirit of earlier pilgrimages, Red Cliff community leaders led 150 residents to the Notch Mountain shelter house in 1976 (Jenkins 1976). Pilgrimage has since continued annually, though not on a scale intended to garner attention. Rev. Carl Walker of Mount of the Holy Cross Lutheran Church in Vail leads a group no larger than 15 people each July to a view of the cross. The persistence of pilgrimage in the geographical imaginations of Mount of the Holy Cross indicates that though the cross may appear imperfect to some, to others it remains sacred. Aside from the sacred mountains of Native Americans, many Americans associate the idea of a sacred mountain with other continents (Bernbaum 1990), yet Mount of the Holy Cross still exemplifies every sense of the term. Furthermore, unlike most other sacred mountains that are primarily understood through sacred texts or oral traditions, the sacredness of Mount of the Holy Cross is interpreted almost exclusively through iconography.

Based on the summit registers, some hikers are on a pilgrimage when they climb the peak, whether as a member of a church group climbing the peak or expressing individual spirituality in comments like "Praise God," "This is God's creation," and "What has God wrought." Conversely, the name of the mountain seems to cause others to express the antithesis of spirituality: "Genuflect, genuflect, 
genuflect. Well, Goddamn!” (17 July 1966); "Pot is fun” (10 August 1968); “If God can make all this he can surely make me holy" (10 August 1995); "Holy Molly" (12 August 1995); "Hot as hell" (3 July 1966). Even with the power of visual imagery, accessibility that offers personal landscape interaction is a key element in the creation and maintenance of mountain symbolism and geographical imaginations.

Mountain imaginations have evolved greatly in the last 50 years to the point where the same peak can be a water wilderness, mountain climbing Mecca, Christian pilgrimage shrine, and an icon for the state or local communities. The exact precision of the cross is less of an issue today than when calls were made for the government to use helicopters to ferry men and supplies to the peak so that the rock could be blasted and bolted to the point of creating a more perfect cross (Colorado Historical Society c. 1950). Keeping with trends is U.S. society, fewer people see the mount in purely religious terms now, even with the continuation of pilgrimage on a limited scale, and when the mountain is called sacred today it is as likely due to its wilderness scenery as its Christian symbolism.

It is difficult to imagine the snowy cross on a Colorado stamp today because of its overt religious symbolism, yet the less-than-perfect cross is a frequent symbol of Colorado wilderness and Fourteeners. The cross appears on the cover of a popular hiking guide (Borneman and Lampert 1998) and on a poster published by the Colorado Fourteeners Initiative, an organization formed in 1994 "to protect and preserve the natural integrity of Colorado's Fourteeners and the quality of the recreational opportunities they provide” (Colorado Fourteeners Initiative 2006).

These secular uses of the cross image indicate how nature has joined Christianity as one of the dominant geographical imaginations of the mountain, but the geographical imaginations of the peak in the days of Jackson and Moran are still 
imbued in the mountain's image. The 2005 Colorado Travel Guide mentions the Notch Mountain trail that leads to a view of "mysterious" Mount of the Holy Cross and its "near-perfect cross" (Colorado 2005, 18). Culturally, the mountain continues to be inseparable from its cross. More than a symbol of diminished religious significance, the changing appearance of the snow-filled couloir is a testament to dynamic geographical imaginations and natural processes, and to the uncertainty that occasionally pervades our understanding of each. 


\section{NOTES}

1. The size of the cross has been subject to much conjecture, with estimates of its height ranging from 1,150 feet to 2,000 feet and estimates of the width of the arms ranging from 400 feet to 750 feet. Fritiof Fryxell (1933) climbed the Cross Couloir and estimated it to be 1,150 feet high and the total width of the arms to be about 400 feet. The elevation of Mount of the Holy Cross is shown on current U.S.G.S. topographic maps as 14,005 feet $(4,268.7 \mathrm{~m})$ above sea level. That elevation is based on the geoid (mean sea level) estimates of the National Geodetic Vertical Datum of 1929 (NGVD 29). The National Geodetic Survey has readjusted its elevation calculations to use the North American Vertical Datum of 1988 (NAVD 88), and if those elevations are adopted on official maps, the Mount of the Holy Cross elevation will be shown as 14,009 feet $(4,269.9 \mathrm{~m})$.

2. The peak was, no doubt, known to the Ute people, and one fanciful account of Jackson's first photograph indicates the Ute Chief Ouray helped Jackson find the peak (Jackson and Marshall 1952). But no evidence suggests this mountain is sacred to the Ute, and the first recorded climb of the peak found no indication of a previous human presence (Bueler 2000).

3. Only the briefest of glimpses of Mount of the Holy Cross are possible from Colorado roadways, such as the west side of Shrine Pass, west side of Fremont Pass, north side of Tennessee Pass, west side of Loveland Pass, south slope of the Mount Evans Highway, and west portal of Eisenhower Tunnel. The peak is also visible from the summit of the Vail Ski Area.

4. The Colorado Mountain Club (CMC) places registers on the summits of selected peaks for climbers to note their name, hometown, and comments. I examined the 
registers for Mount of the Holy Cross in the CMC collection, held in the Henry S. Hall, Jr. American Alpine Club Library in Golden, Colorado.

5. Holy Cross National Forest became part of White River National Forest in 1945.

6. Holy Cross National Monument was the fifth such designation in Colorado, following Wheeler, Colorado, Yucca House, and Hovenweep national monuments, yet the significance of Mount of the Holy Cross as a national shrine is suggested by its proclamation as a national monument prior to the monuments at Great Sand Dunes, Black Canyon of the Gunnison (each later designated a national park), and Dinosaur.

7. House Resolution 7339 provides no rationale for abolishing the national monument and returning the lands to the national forest. Wheeler National Monument was abolished at the same time.

8. Estimates of how many people climbed the mountain are reflected in the available registers, including 19 in 1954, 4 in 1955, 52 in 1956, 2 in 1957, and 65 in 1958. Single outings of large numbers of climbers account for much of the fluctuation, such as the group of 37 climbers on 4 July 1958 from the Mountain Recreation Department at the University of Colorado. 


\section{REFERENCES}

Among the Rockies: Pictures of magnificent scenes in the Rocky Mountains. 1907. Denver: The H.H. Tammen Curio Co.

And now, our own sacred mountain. 1933. Appalachia 19(4): 595-596.

Arreola, D. D. 2001. La cerca y las garitas de Ambos Nogales: A postcard landscape exploration. Journal of the Southwest 43(4): 505-541.

Bergin, M. 1923. The Holy Cross outing. Trail \& Timberline 56: 11

Bernbaum, E. 1990. Sacred mountains of the world. San Francisco: Sierra Club Books.

Birch, A. G. 1935. U. S. Improvement work ordered in Holy Cross area. The Denver Post, 14 August, 1, 8.

Blake, K. S. 1999a. Peaks of Identity in Colorado’s San Juan Mountains. Journal of Cultural Geography 18(2): 29-55. . 1999b. Sacred and Secular Landscape Symbolism at Mount Taylor, New

Mexico. Journal of the Southwest 41(4): 487-509.

. 2002. Colorado Fourteeners and the Nature of Place Identity. Geographical Review 92(2): 155-179.

2005. Mountain Symbolism and Geographical Imaginations. Cultural

Geographies 12(4): 527-531.

Borneman, W. R., and T. Caudle. 2005. 14,000 Feet: A celebration of Colorado's highest mountains. Pueblo: Skyline Press.

Borneman, W. R., and L. J. Lampert. 1998. A Climbing guide to Colorado's Fourteeners. 3d ed. Boulder: Pruett Publishing Co.

Bouck, C. 1923. Twelfth annual outing. Trail \& Timberline 61: 1-2.

Bowles, S. 1991 [1868]. The parks and mountains of Colorado: A summer vacation in the Switzerland of America. Norman: University of Oklahoma Press. 
Brewer, W. H. 1930. Rocky Mountain letters, 1869: A journal of an early geological expedition to the Colorado Rockies, edited by E. B. Rogers. Denver: Colorado Mountain Club. Brown, R. L. 1968. William Henry Jackson and Mount of the Holy Cross. Trail \& Timberline 590: 37-41. 1970. Holy Cross: The mountain and the city. Caldwell, ID: Caxton Printers.

Bueler, W. M. 2000 [1974]. Roof of the Rockies: A history of Colorado mountaineering. 3d ed. Golden: Colorado Mountain Club.

Carhart, A. H. 1932. Colorado. New York: Coward-McCann.

Chapin, F. H. 1995. Frederick Chapin's Colorado: The peaks about Estes Park and other writings, edited by J. H. Pickering. Niwot: University Press of Colorado. Colorado Fourteeners Initiative. 2006. http://www.14ers.org (last accessed 22 December 2006).

Colorado Historical Society. Collection no. 475, Elmer E. Owen. File folder 23, manuscript 475. Restore the Mount of the Holy Cross.

Colorado Official State Vacation Guide. 2005. Denver: Weaver Official Publications. Cosgrove, D. E. 1984. Social formation and symbolic landscape. London: Croom Helm. , and S. Daniels. 1988. The iconography of landscape: Essays on the symbolic representation, use, and design of past environments. New York: Cambridge University Press. Crofutt, G. A. 1981 [1885]. Crofutt's grip-sack guide of Colorado, volume II. Boulder: Johnson Books.

Crouter, G. 1977. The Majestic Fourteeners: Colorado's highest. Silverton: Sundance Books. Crowley, J. M. 1975. Ranching in the mountain parks of Colorado. Geographical Review 65(4): 445-460.

DeLyser, D., and P. F. Starrs. 2001. Doing fieldwork: Editors' introduction. Geographical Review 91(1\&2): iv-viii. 
Douglas, W. O. 1961. My wilderness: East to Katahdin. Garden City, NY: Doubleday.

Eberhart, P., and P. Schmuck. 1970. The Fourteeners: Colorado's great mountains. Chicago: Sage Books.

Field, E. 1896. The Holy Cross: And other tales. New York: Charles Scribner's Sons.

Foster, M. 1987. Historical hide 'n seek. Trail \& Timberline 823: 270-271.

Francaviglia, R. V. 2003. Believing in place: A spiritual geography of the Great Basin. Reno:

University of Nevada Press.

Fryxell, F. 1933. Climbing the cross of snow. The Canadian Alpine Journal 21: 28-32. 1934. The Mount of the Holy Cross. Trail \& Timberline 183: 3-9, 14. . 1952. Foreword to Quest of the snowy cross, by C. S. Jackson and L. W.

Marshall, 7-12. Denver: University of Denver Press.

Gaug, M. 2003. Hiking Colorado. 2d ed. Guilford, CT: Globe Pequot Press.

Gilliland, M. E. 2004. The Vail hiker and ski touring guide. 4th ed. Silverthorne, CO:

Alpenrose Press.

Goetzmann, W. H., and W. N. Goetzmann. 1986. The West of the imagination. New

York: W.W. Norton \& Company.

Hales, P. B. 1988. William Henry Jackson and the transformation of the American landscape.

Philadelphia: Temple University Press.

Holmes, W. H. 1875. The Mountain of the Holy Cross. The Illustrated Christian Weekly, 1 May, 209-210.

Hoover, H. 1929. Holy Cross National Monument. Proclamation 1877: May 11 (46 Stat. 2993).

Illg, G., and R. McClellan. 1983. Wetlands at stake in Homestake II. Trail \& Timberline 776, 777: 155-156. 
Ingram, T. R. 1901. A trip to the Rockies: March and two step. Denver: Tolbert R. Ingram Music Co.

Jackson, C. S., and L. W. Marshall. 1952. Quest of the snowy cross. Denver: University of Denver Press.

Jackson, W. H. 2005 [1929]. William Henry Jackson's “The pioneer photographer.” Ed. B.

Blair. Santa Fe: The Museum of New Mexico Press.

Jakle, J. A. 2003. Postcards of the night: Views of American cities. Santa Fe: Museum of New Mexico Press.

Jenkins, T. M. 1976. The cross of snow. Summit 22(6): 18-21, 44.

Kerasote, T. 1987. Confessions of a ski mountaineer. Climbing 104: 64-67.

Kerin, S. 1922. Poems of sunny Colorado. Denver: Welch-Haffner Printing Co.

Kinsey, J. L. 1992. Thomas Moran and the surveying of the American West. Washington, DC: Smithsonian Institution Press.

Lavender, D. 1976. David Lavender's Colorado. Garden City, NY: Doubleday.

Lipsher, S. 2005. A stain on the land. The Denver Post, 15 August, A1.

Longfellow, H. W. 2000. Poems and other writings, edited by J. D. McClatchy. New York: Library of America.

Macfarlane, R. 2003. Mountains of the mind. New York: Pantheon.

Meinig, D. W., ed. 1979. Symbolic landscapes: Some idealizations of American

communities. In The Interpretation of Ordinary Landscapes: Geographical essays, 164-192.

New York: Oxford University Press.

Muir, J. 1993 [1894]. The mountains of California. New York: Barnes \& Noble.

Nash, R. 1967. Wilderness and the American mind. New Haven: Yale University Press.

Nicolson, M. H. 1997 [1959]. Mountain gloom and mountain glory: The development of the aesthetics of the infinite. Seattle: University of Washington Press. 
Parsons, E. 1911. A guidebook to Colorado. Boston: Little, Brown, and Co.

Picturesque Colorado: A story of the attractions of the wonderful Rocky Mountain region told in

pictures and words. 1909. Denver: Colorado \& Southern Railway.

Parsons, J. J. 1977. Geography as exploration and discovery. Annals of the Association of American Geographers 67(1): 1-16.

Powell, J. W. 1961 [1895]. The exploration of the Colorado River and its canyons. New York:

Dover Publications.

Roach, G.. 1999. Colorado's Fourteeners: From bikes to climbs. 3d ed. Golden, CO: Fulcrum Publishing. Runte, A. 1979. National parks: The American experience. Lincoln: University of Nebraska Press.

Shortridge, J. R. 2000. Our town on the plains: J. J. Pennell's photographs of Junction City,

Kansas, 1893-1922. Lawrence: University Press of Kansas.

Stewart, G. R. 1953. U.S. 40: Cross section of the United States of America. Cambridge, MA: Riverside Press.

Tuan, Y. 1974. Topophilia: A study of environmental perception, attitudes and values.

Englewood Cliffs: Prentice-Hall.

Vale, T. R., and G. R. Vale. 1983. U.S. 40 today: Thirty years of landscape change in America. Madison: University of Wisconsin Press. . 1989. Western images, western landscapes: Travels along U.S. 89. Tucson:

University of Arizona Press. 1994. Time and the Tuolumne landscape: Continuity and change in the Yosemite bigh country. Salt Lake City: University of Utah Press.

Vale, T. R. 1995. Mountains and moisture in the West. In The Mountainous West: Explorations in historical geography, ed. W. Wyckoff and L. M. Dilsaver, 141-166. Lincoln: University of Nebraska Press. 
Vickery, A. 1988. Holy Cross Wilderness Area proposals. Trail \& Timberline 831: 186187.

Wolle, M. S. 1949. Stampede to timberline: The ghost towns and mining camps of Colorado.

Chicago: Sage Books.

Wright, J. K. 1947. Terrae incognitae: The place of the imagination in geography.

Annals of the Association of American Geographers 37(1): 1-15. . 1966. The heights of mountains: "An historical notice." In Human nature in geography: Fourteen papers, 1925-1965, 140-155. Cambridge: Harvard University Press. Wyckoff, W., and L. M. Dilsaver. 1995. The Mountainous West: Explorations in historical geography. Lincoln: University of Nebraska Press.

Wyckoff, W. 1999. Creating Colorado: The making of a western American landscape, 1860-

1940. New Haven: Yale University Press. 2006. On the road again: Montana's changing landscape. Seattle: University of Washington Press. 


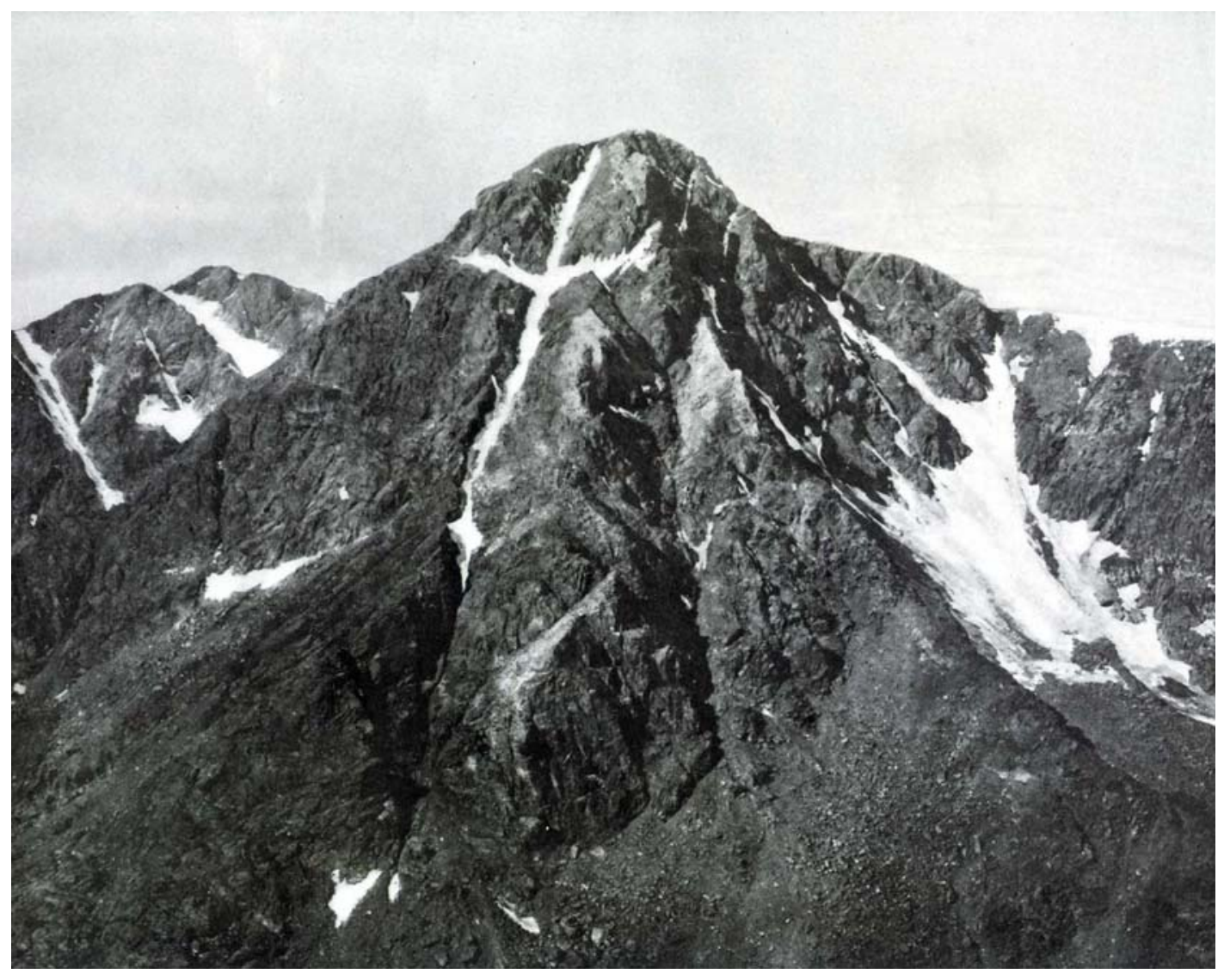

Fig. 1 - Mount of the Holy Cross, photographed by William Henry Jackson on 24

August 1873 from Notch Mountain. From Among the Rockies: Pictures of Magnificent Scenes in the Rocky Mountains (1907, H. H. Tammen Curio Co., Denver). The snowfield to the right of the cross has been likened to a supplicating Madonna or angel. The caption to the photograph includes these phrases: "this snow white banner of Christian faith ... the symbol is perfect ... this sign set in the heavens." (Reproduced from the collection of the author) 


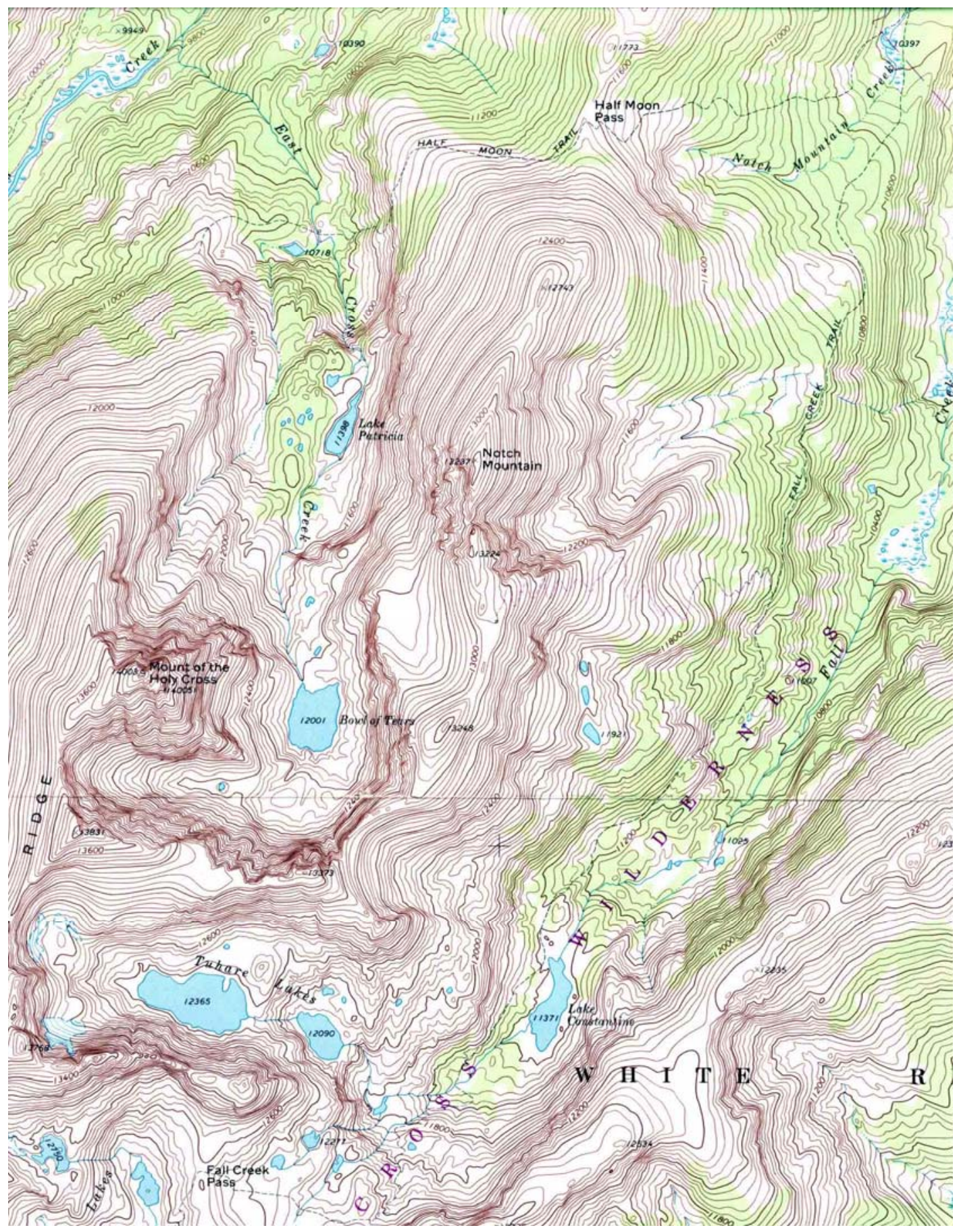

Fig. 2 - Detail of a topographic map of "Mount of the Holy Cross Quadrangle," 7.5

minute series, scale 1:24,000, contour interval 40 feet. Published by the U.S.

Geological Survey, 1970, photorevised 1987. 


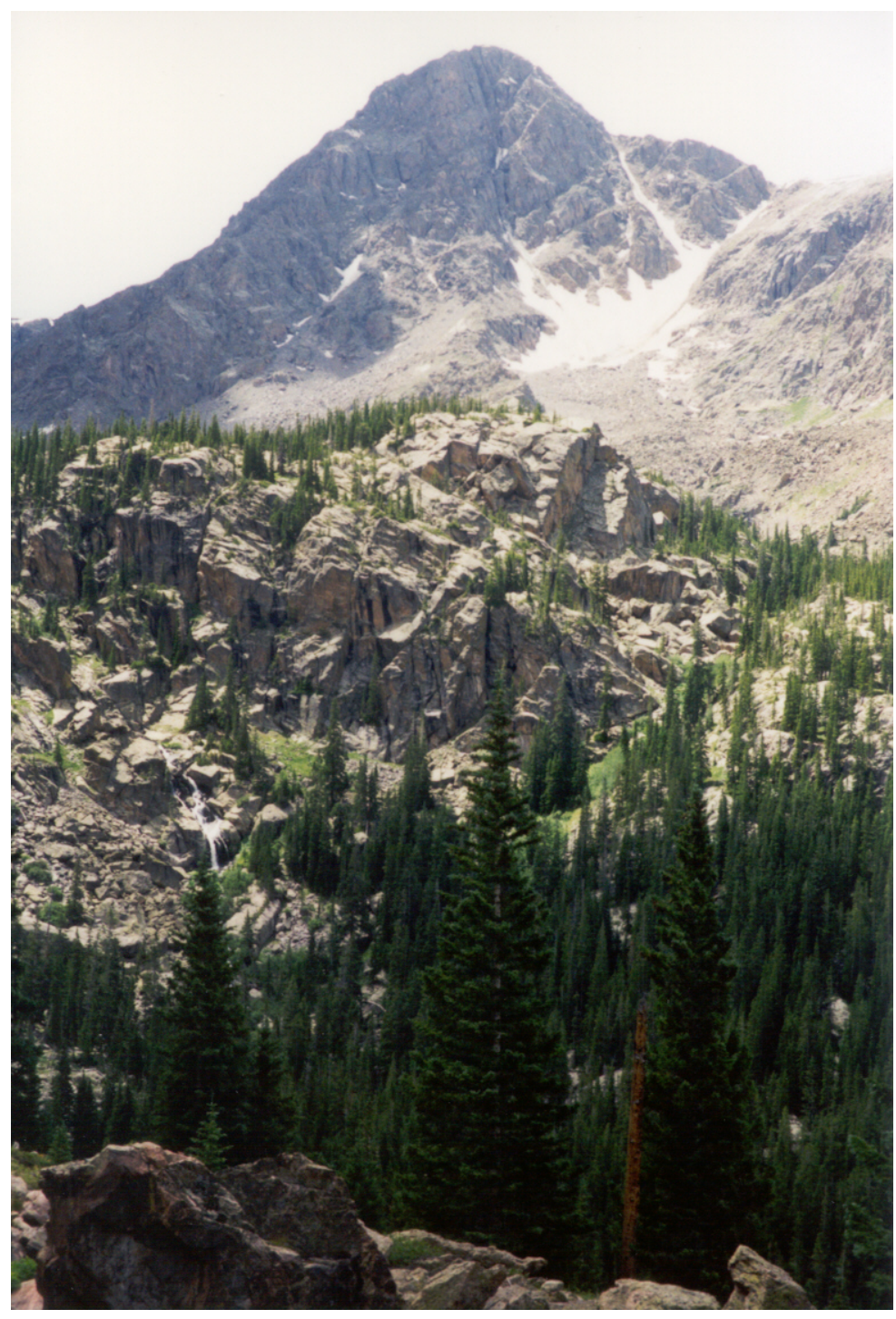

Fig. 3 - View of the north face of Mount of the Holy Cross from near East Cross

Creek along the main hiking route to the summit. Barely visible in the rocks at the left center of the photograph is a waterfall along East Cross Creek. The snowfield on the peak is part of the Supplicating Virgin, and the cross is out of view over the left ridge of the peak. (Photograph by the author, July 1998) 


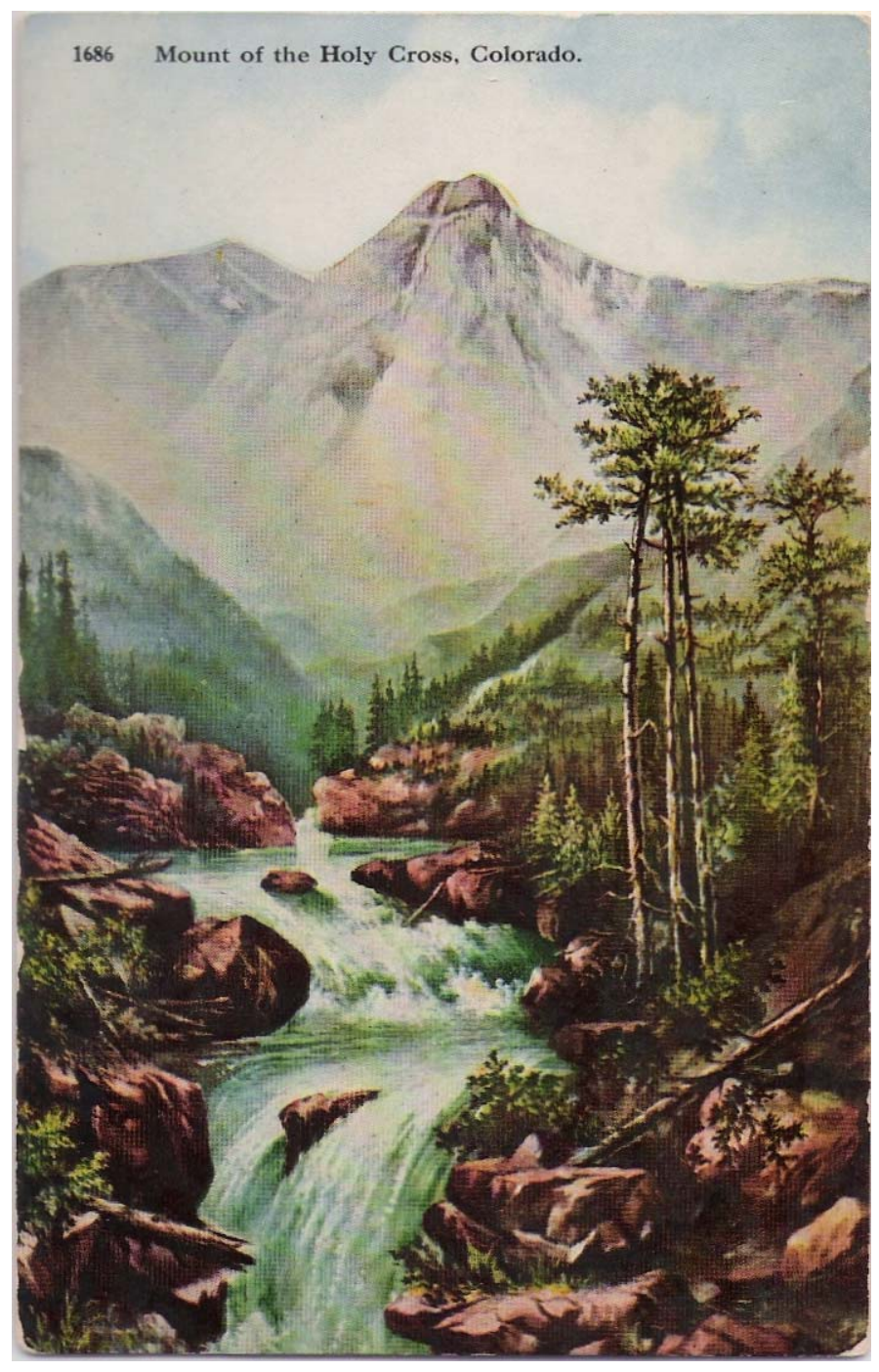

Fig. 4 - Color lithograph postcard of Mount of the Holy Cross, adapted from Thomas Moran's 1875 painting. Cross Creek is in the foreground, along with a hint of the fallen timber that hindered the progress of the 1873 Hayden Survey and Moran's visit in 1874. A postmark on the reverse is dated 1914. (Reproduced from the collection of the author) 


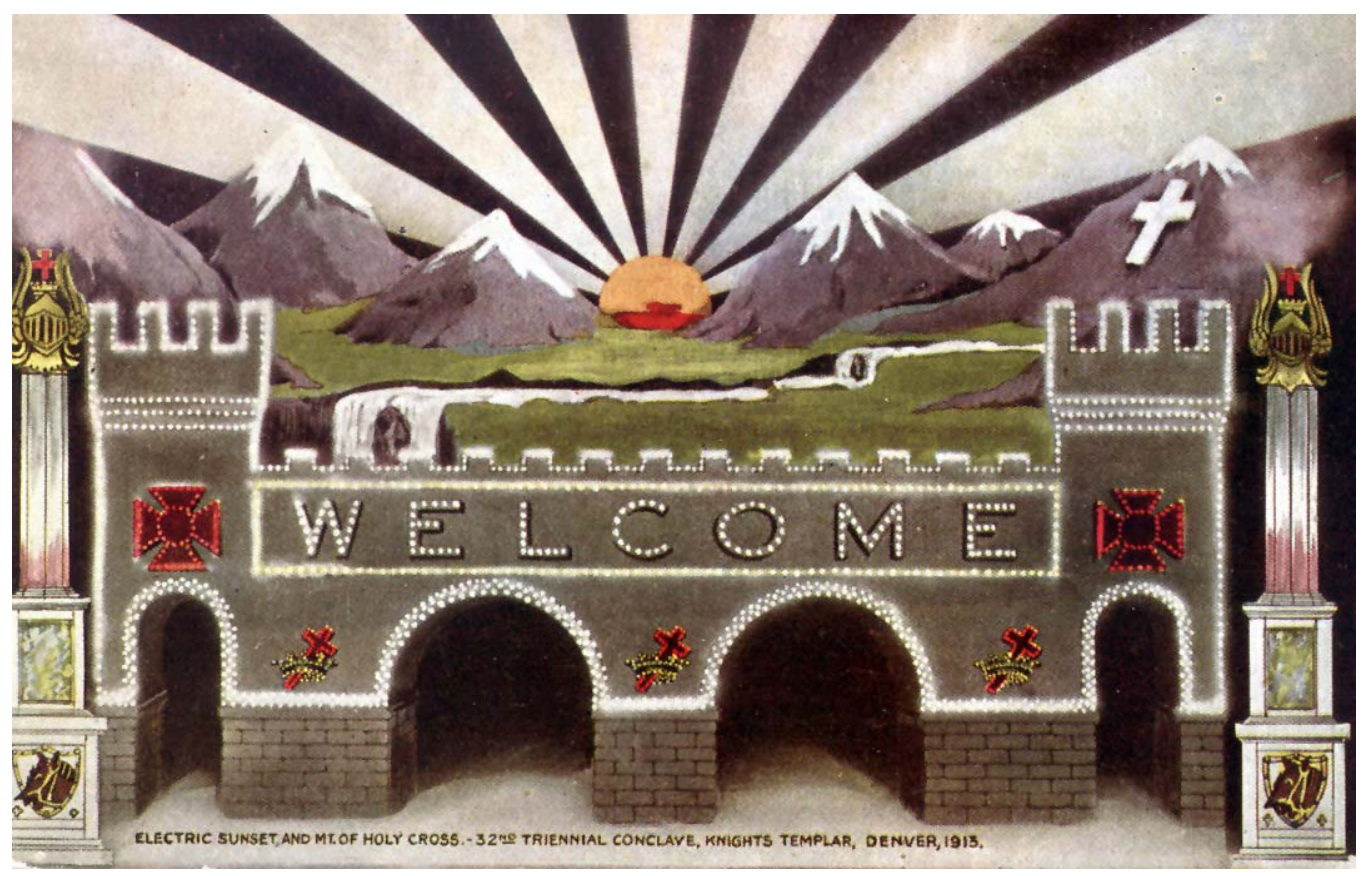

Fig. 5 - Color lithograph postcard commemorating the $32^{\text {nd }}$ Triennial Conclave of the Knights Templar in Denver, 1913. The caption refers to the imitation of Mount of the Holy Cross on the right side of the picture. Published by George E. Turner and printed by Williamson-Haffner Company, Denver. (Reproduced from the collection of the author) 


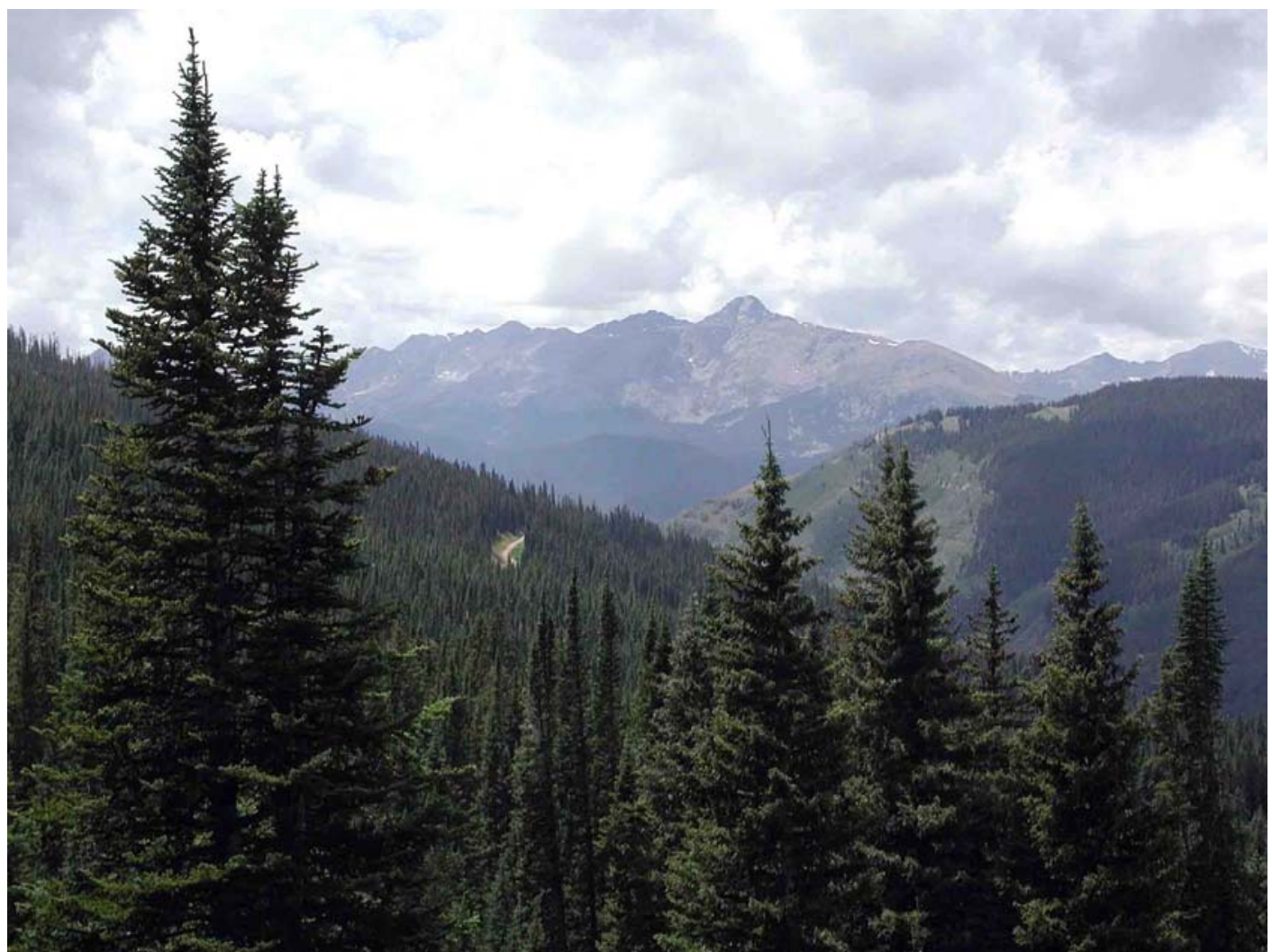

Fig. 6 - View of the summit of Mount of the Holy Cross from a Forest Service viewpoint along Shrine Pass, approximately 13 miles northeast of the peak. From this vantage, Notch Mountain blocks the lower portion of the Cross Couloir. (Photograph by the author, July 2001) 


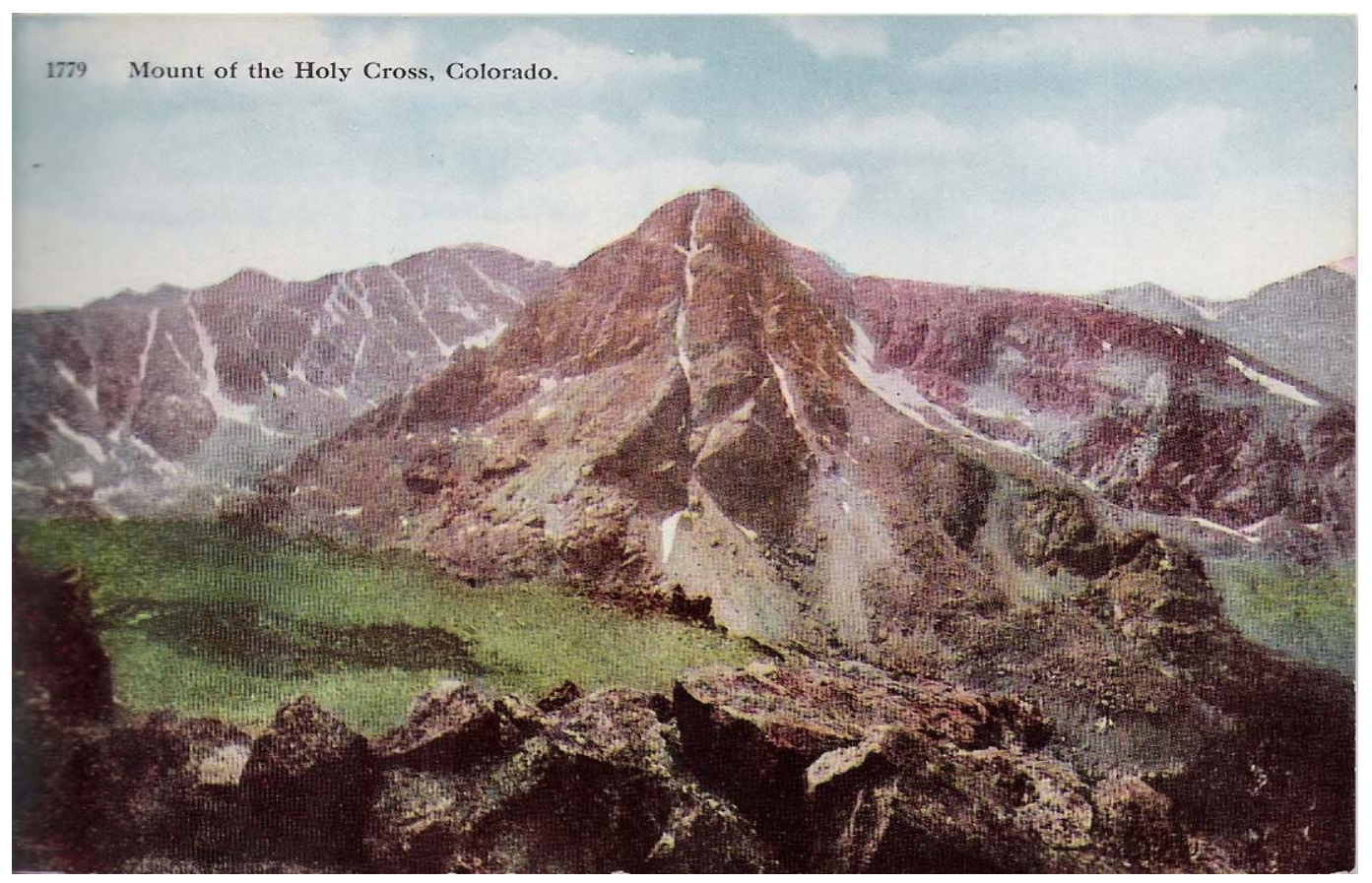

Fig. 7 - Color lithograph postcard of Mount of the Holy Cross from Notch Mountain.

The appearance of the snowy cross has long been subject to the time of year and annual variability. Published in about 1907-1916 (publisher unknown). (Reproduced from the collection of the author) 


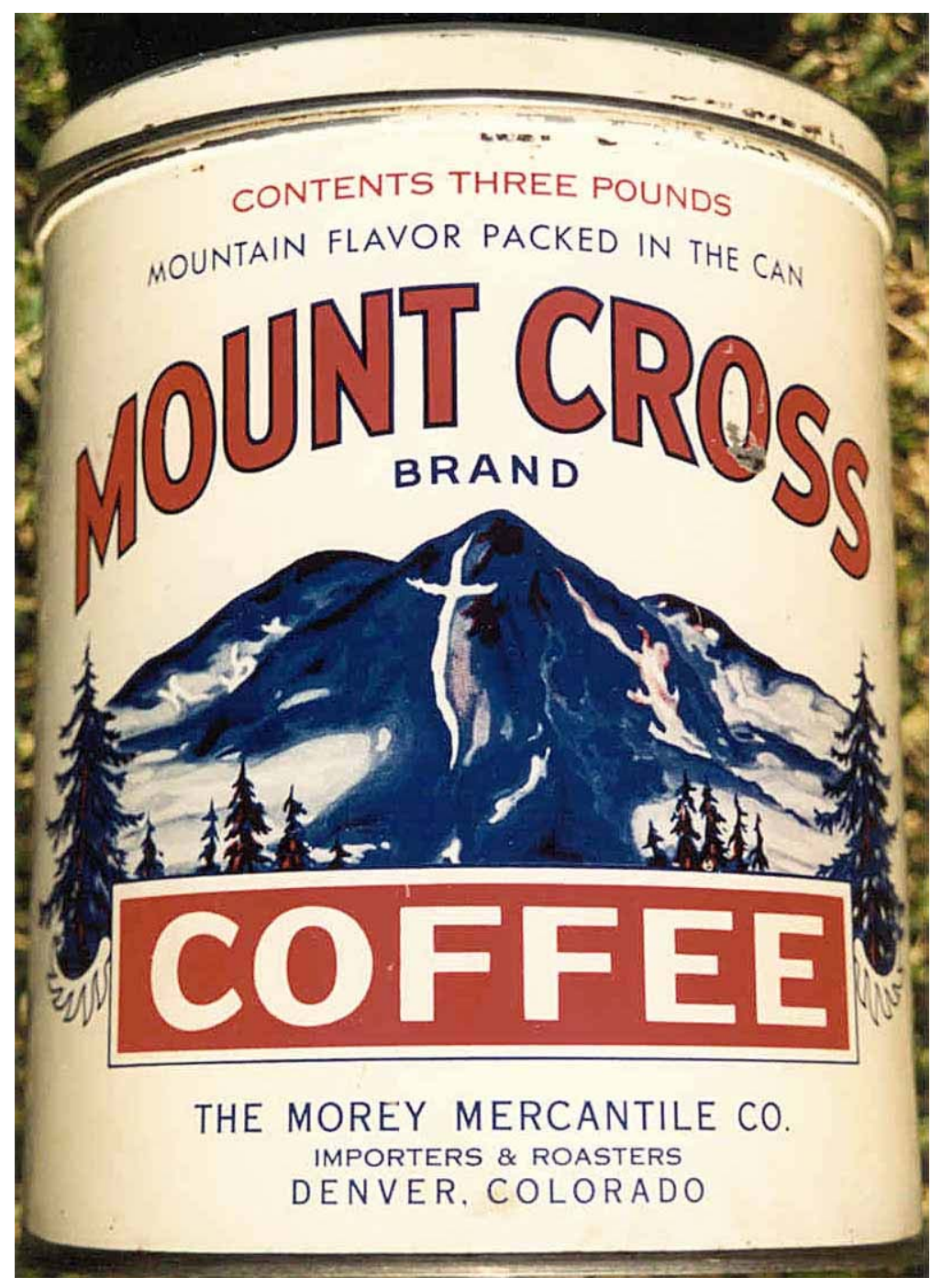

Fig. 8 - Mount Cross coffee can, date unknown. (Reproduced from the collection of the author) 

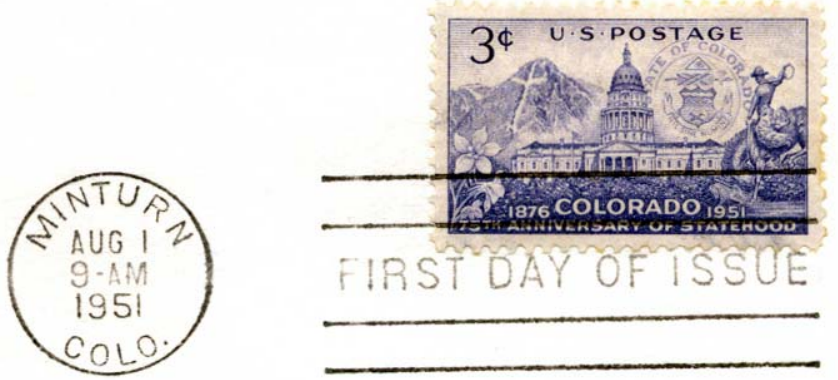

Fig. 9 - Commemorative stamp issued in 1951 for Colorado's $75^{\text {th }}$ statehood anniversary. A reproduction of Jackson's photograph of Mount of the Holy Cross appears with the Colorado State Capitol, the bucking bronco statue on the capitol grounds, the state seal, and the state flower (columbine). The first day of issue was postmarked from Minturn, Colorado on August 1. (Reproduced from a First Day Cover in the collection of the author) 


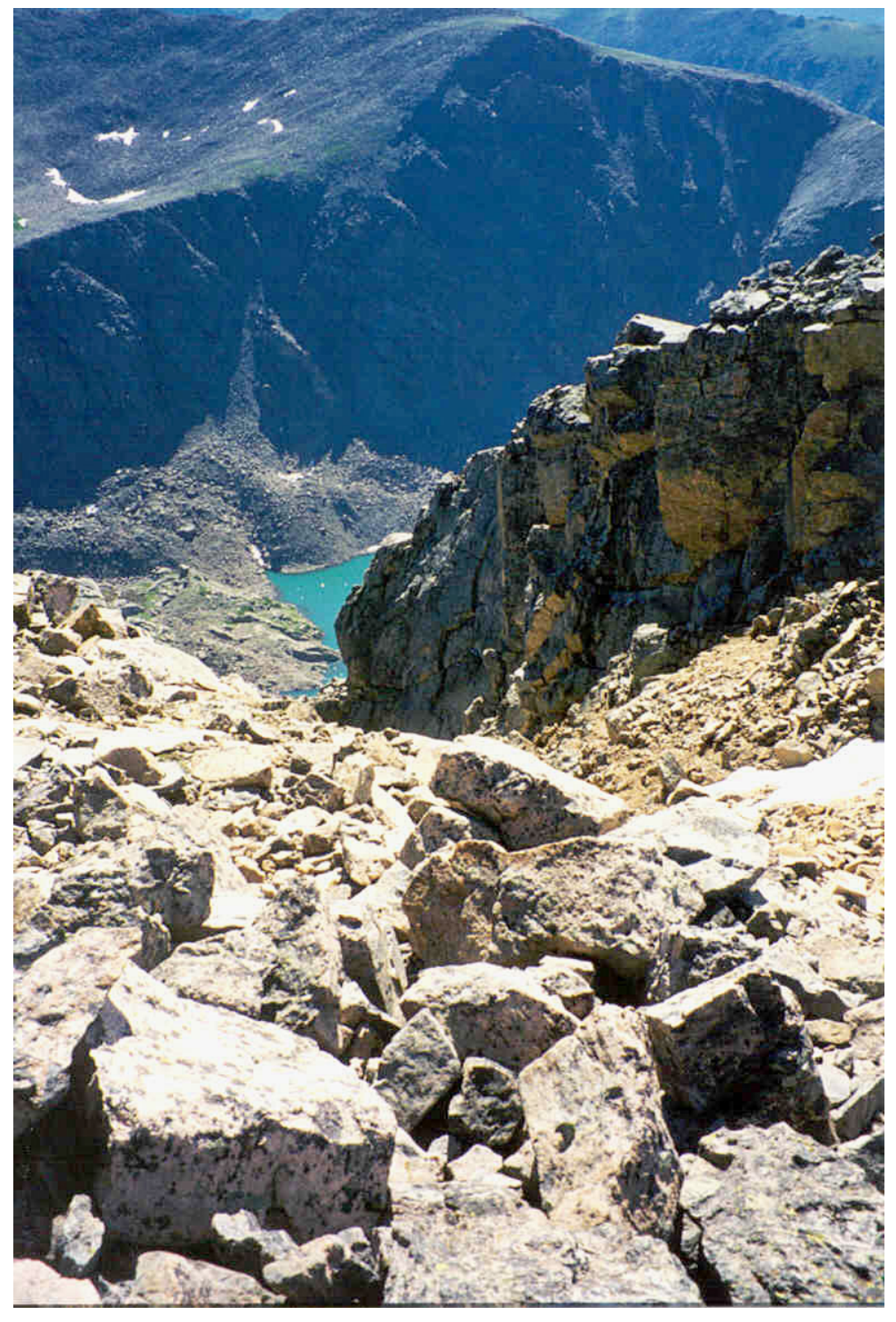

Fig. 10 - View from the summit of Mount of the Holy Cross straight down the Cross

Couloir to the Bowl of Tears, 2,000 feet below. The southern ridge of Notch

Mountain rises behind the tarn. (Photograph by the author, July 1998) 


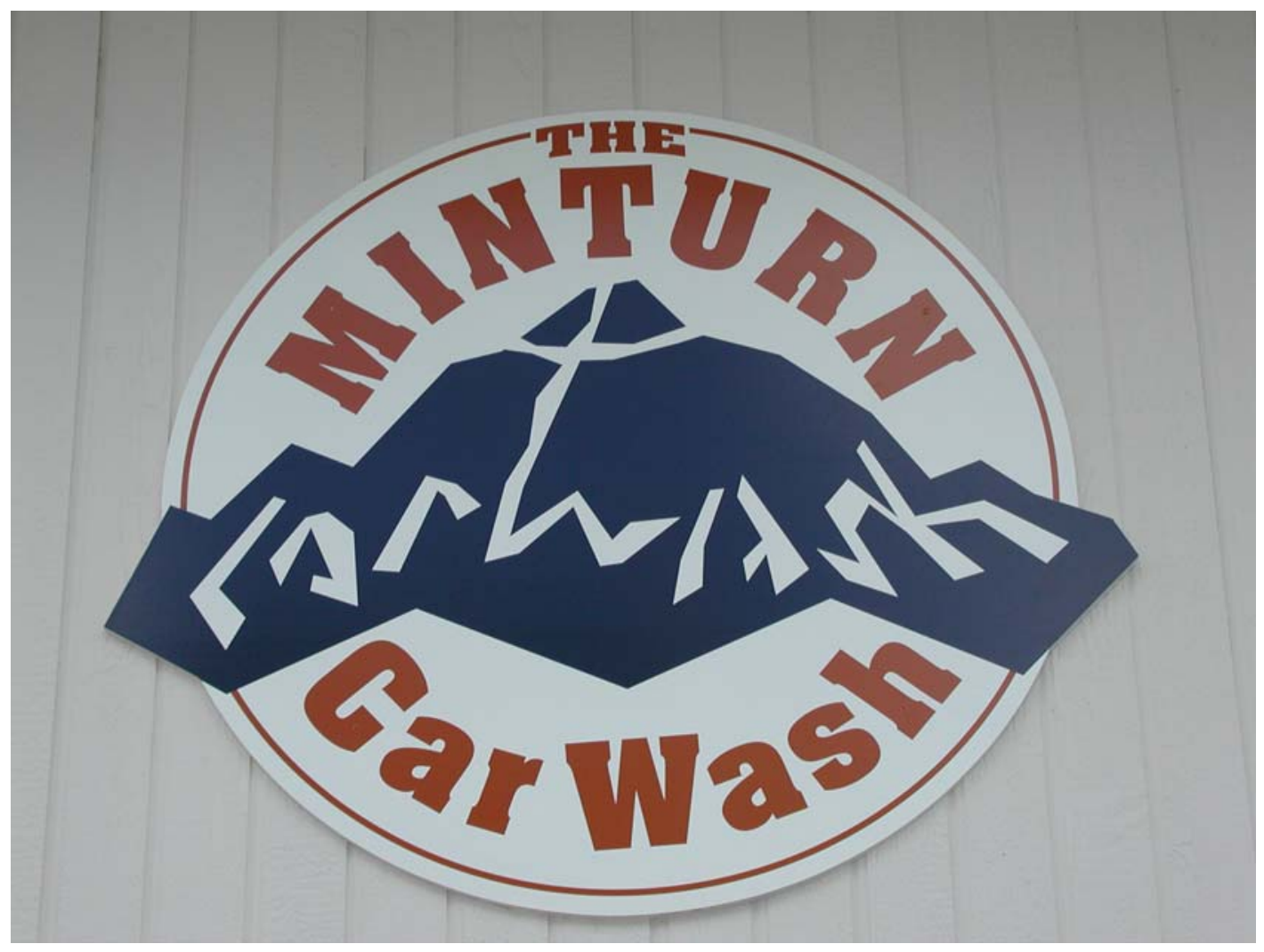

Fig. 11 - Logo of The Minturn Car Wash, Minturn, Colorado. (Photograph by the author, June 2004) 